\title{
Analysis of Fetal and Placental Development in Rats after Administration of Hydroalcoholic Extract from the Root of Petiveria alliacea L. (Phytolaccaceae)
}

\author{
Análisis del Desarrollo Fetal y Placenta en Ratas Después de la Administración \\ de Extracto Hidroalcohólico de la Raíz de Petiveria alliacea L. (Phytolaccaceae)
}

\author{
"Carina Scanoni Maia; **Valéria Wanderley Teixeira; ${ }^{* *}$ Álvaro Aguiar Coelho Teixeira \& *Nicodemos Teles Pontes Filho
}

MAIA, C. S.; WANDERLEY-TEIXEIRA, V.; TEIXEIRA, A. A. C. \& PONTES FILHO, N. T. Analysis of fetal and placental development in rats after administration of hydroalcoholic extract from the root of Petiveria alliacea L. (Phytolaccaceae). Int. J. Morphol., 28(1):165-169, 2010.

SUMMARY: We investigated the effect of hydroalcoholic extract the Petiveria alliacea root on fetal and placental development female rats pregnancy. Thirty female rats were mated and divided in groups: I - rats treated with placebo and sacrificed on the $7^{\text {th }}$ day; II - rats treated with hydroalcoholic extract and sacrificed on the $7^{\text {th }}$ day; III - rats treated with placebo and sacrificed on the $14^{\text {th }}$ day; IV - rats treated with hydroalcoholic extract and sacrificed on the $14^{\text {th }}$ day; V - rats treated with placebo for analysis of the offspring; VI - rats treated with hydroalcoholic extract for analysis of the offspring. The extract was administered by gavage in the dosage of $18 \mathrm{mg} / \mathrm{kg}$ body wt., in $5^{\text {th }}$ day of pregnancy. The implantation sites and placenta were fixed in Bouin and processed for the embedding in paraffin. The offspring were weighed, measured and counted. The hydroalcoholic extract of the root of the $P$. alliacea causes significant reduction in the number of implantation sites, but do not cause histological alterations in these sites and placenta. No alterations in the number, length and weight have been observed in offspring. Our results suggest that the hydroalcoholic extract from the $P$. alliacea in the dosage of $18 \mathrm{mg} / \mathrm{kg}$ body wt., administered to female rats, on the $5^{\text {th }}$ day of pregnancy, only cause a retard in the implantation process.

KEY WORDS: Petiveria alliacea; Uterus; Placenta; Hydroalcoholic extract.

\section{INTRODUCTION}

The Petiveria alliacea L. (Phytolaccaceae), is a herbaceous plant, widely distributed in Brazil and was very important in the period of slavery, because the slaves already knew their toxic and sedative effects, giving it the significant name of "to tame the master", but is also known as guinea (Corrêa, 1984). In several regions of the world is popularly used as antispasms, diuretic and diaphoretic, being used as a weak infusion of the leaves or roots against hydropsy, arthritis, rheumatism, malaria, poor memory and to induce abortion (Mors et al., 2000). It also presents antinociceptive action (Gomes et al., 2005), and analgesic anti inflammatory (Lopes-Martins et al., 2002) and hypoglycemic (GarcíaGonzalez et al., 2006).

Several studies have shown some properties of the extract of $P$. alliacea. The hydroalcoholic extract is popularly used as vermifuge, also showed antiviral activity (Ruffa $e t$ $a l ., 2002)$. But the aqueous extract of leaves of the plant presents activity gastroprotective (Cortez et al., 1998), hematopoietic (Quadros et al., 1999) however, may be hepatotoxic (Torres et al., 2007).

Peters et al. (1988), studying the effect of various doses of extracts from the leaves of $P$. alliace in pregnant rats, found that the hydroalcoholic extract $(18 \mathrm{mg} / \mathrm{kg})$ has zigotoxic and anti-implantation effect, and that the watersoluble fraction $(20 \mathrm{mg} / \mathrm{kg})$ has abortifacient effect. Already Guerra et al. (1989) observed that the aqueous effects of extract of the roots $(200 \mathrm{mg} / \mathrm{kg})$ and leaves $(100 \mathrm{mg} / \mathrm{kg})$ have anti-implantation effect, while the stem $(100 \mathrm{mg} / \mathrm{kg})$ seems to have zigotoxic effect. However, no reports in the literature on the histological aspects the endometrium and blastocyst interaction, and its possible teratogenic effect on the offspring. Thus, we investigated the effect of the hydroalcoholic extract in rats on fetal and placental development during pregnancy.

* Program of Graduate Studies in General Patology, Department of Patology, University Federal of Pernambuco - UFPE. Recife-Brasil

${ }^{* *}$ Program of Graduate Studies in Animal Bioscience, Department of Morfology and Fisiology Animal, University Federal Rural de Pernambuco-UFRPE. Recife-Brasil. 


\section{MATERIAL AND METHOD}

The roots of $P$. alliacea were collected in January 2009 in the city of Limoeiro, Pernambuco-Brazil. Thirty female rats were used (Rattus norvegicus albinus), Wistar strain, 90 days of age and weighing approximately $200 \mathrm{~g}$. The animals were confined and kept in cages with food and water "ad libitum", temperature of $22^{\circ} \mathrm{C}$ and artificial lighting, in a photoperiod of 12 hours in the light and 12 hours in the dark. The study protocol was approved by the Animal Ethics Committee of University Federal Rural of Pernambuco. The animals were mated and divided, randomly, into six groups: I - rats treated with placebo on the $5^{\text {th }}$ day of pregnancy and sacrificed on the $7^{\text {th }}$ day (control); II - rats treated with hydroalcoholic extract on the $5^{\text {th }}$ day of pregnancy and sacrificed on the $7^{\text {th }}$ day; III - rats treated with placebo on the $5^{\text {th }}$ day of pregnancy and sacrificed on the $14^{\text {th }}$ day (control); IV - rats treated with hydroalcoholic extract on the $5^{\text {th }}$ day of pregnancy and sacrificed on the $14^{\text {th }}$ day; $\mathrm{V}$ - rats treated with placebo on the $5^{\text {th }}$ day of pregnancy for analysis of the offspring (control); VI - rats treated with hydroalcoholic extract on the $5^{\text {th }}$ day of pregnancy for analysis of the offspring. Animals were treated with $18 \mathrm{mg} / \mathrm{kg}$ body wt., of the hydroalcoholic extract orally, which were diluted in $0.5 \mathrm{~mL}$ of $1 \%$ aqueous agar (Difco) solution, on the fifth day of pregnancy for females in Group II, IV, VI, following the methodology described by Guerra et al. and Gomes et al. (2008). For females in Group I, III, V was administered by the same route, only $0.5 \mathrm{~mL}$ of $1 \%$ aqueous agar (Difco) solution. The animals were anesthetized with ketamine hydrochloride $(80 \mathrm{mg} / \mathrm{kg}$ ) and xylazine $(6 \mathrm{mg} / \mathrm{kg})$ IM. The uterine horns containing implantation sites and placentas were fixed in Boüin for 48 hours, processed for embed in paraffin and section stained with hematoxylin-eosin (H.E.). The offspring, which were counted, measured using a caliper and weighed on analytical scale. The macroscopic analysis was done by looking for any possible malformation visible, and the change in weight and size of offspring. The average number of sites of deployment, weight, number and size of the newborns were submitted to non-parametric test Mann-Witney, and when needed, compared by Dunn's test $(\mathrm{P}<0.05)$.

\section{RESULTS}

The animals of group II showed significant reduction in the number of implanted sites (Table I). Histological analysis of implantation sites of the rats in groups I and II showed that they were fully inserted in the wall of the uterus, and well developed. In endometrial stroma showed decidual
Table I. Average and standard deviation of number implantation sites. 1 Average followed by the same letter does not differ statistically amongst them by Dunn's test ( $\mathrm{P}$ $\leq 0.05)$.

\begin{tabular}{cc}
\hline Groups & Number Implantation Sites \\
\hline I & $12.8 \pm 0.83 \mathrm{a}$ \\
II & $10.6 \pm 0.89 \mathrm{~b}$ \\
\hline
\end{tabular}

reaction is where the most common cell types were decidual cells, leukocytes and macrophages (Figs. 1A and 1B). We also notice the presence of a large number of endometrial glands that are usually located near the implantation sites. The trophoblasts are presented in various stages of development; beside of cytotrophoblast cells with relatively large nuclei, vesicular, clear cytoplasm and mitotic activity, where some showed polyploidy (Fig. 1C). No observed formation of syncytiotrophoblast in the sites. The placentas with fourteen days of development of animals in groups III and IV also showed the same histological features, characterized by the presence of regions of labyrinth, trophospongium and giant trophoblastic cells (Fig. 1D). There was no statistically significant difference in the number, length and weight of newborns in the experimental groups (Table II). No malformations were observed in the head, trunk and limbs of offspring.

Table II. Average and standard deviation of number, weight and length of offspring. 1 Average followed by the same letter does not differ statistically amongst them by Dunn's test $(\mathrm{P} \leq 0.05)$.

\begin{tabular}{cccc}
\hline Groups & Number & Weight $(g)$ & Length \\
\hline V & $11.40 \pm 2.64 \mathrm{a}$ & $6.20 \pm 0.81 \mathrm{a}$ & $6.41 \pm$ \\
VI & $9.80 \pm 1.09 \mathrm{a}$ & $6.36 \pm 0.12 \mathrm{a}$ & $6.45 \pm$ \\
\hline
\end{tabular}

\section{DISCUSSION}

The hydroalcoholic extract from the root of the plant $P$. alliacea in the studied dosage, in fact did not prove as having anti-implantation effect, because the number of newborns was not different from the control group, even with a statistically significant decrease in the number of sites located in the treated rats, in spite of reductions in the number of deployed sites have also been reported by Peters et al. and Guerra et al. in rats treated with aqueous extract of this plant. However, Peters et al. reported that the hydroalcoholic extract, in the dosage of $18 \mathrm{mg} / \mathrm{Kg}$ administered in 3th or 


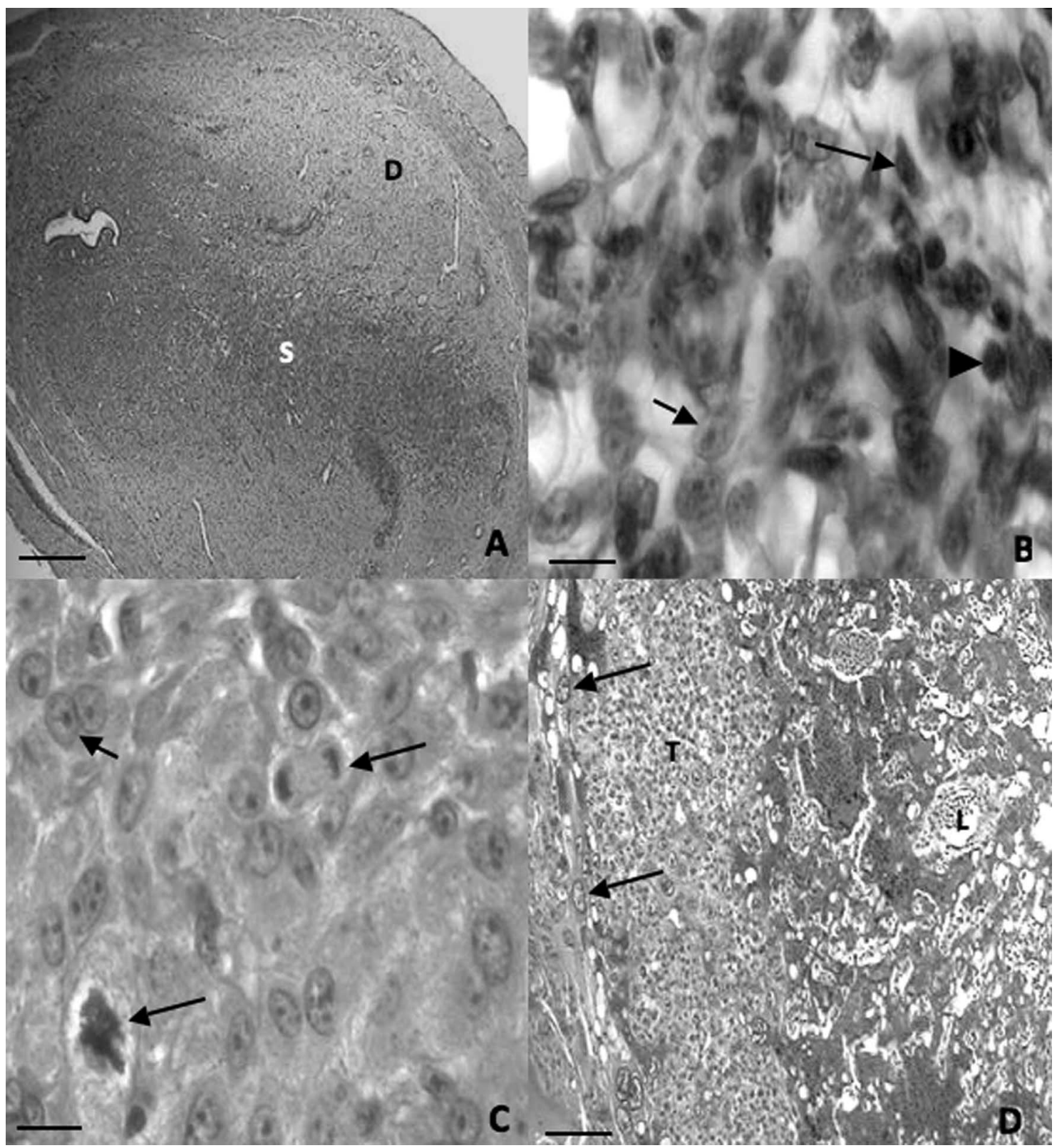

Fig. 1. (A). Implantation site (S) in development and deciduous (D). H.E. Barr $=200 \mathrm{~mm}$. (B). Decidua showing macrophages (long arrow), decidual cells (short arrow) and leukocyte (arrowhead). H.E. Barr $=25 \mathrm{~mm}$. (C). Implantation site showing trophoblasts in mitotic division (long arrows) and polyploidy cytotrophoblast (short arrow). H.E. Barr = $25 \mathrm{~mm}$. (D). Placenta showing the regions of the labyrinth (L), trofospongium (T) and trophoblastic giant cells (arrows). H.E. Barr $=50 \mathrm{~mm}$.

5th days of gestation, had only zigotoxic effect, which says that the small number of zygotes implanted indicate an intercepted property of the extract. The implantation is a critical point in the gestation of mammals (Paria et al., 2001). This suggest that there was only a retard in the process of implantation in the treated rats, which resulted in the reduction of implantation sites and not necessarily an abortifacient effect, to some extent contrary to the assumptions of Peters et al. According to Oluwole \&
Bolarinwa (1998) the extract of seeds of this plant when administered in rats during pregnancy, stimulates uterine contractions thereby inducing abortion. De Lima et al. (1991) reported that the aqueous extract of root of $P$. alliacea abdominal constrictions in rats produces. Thus, we could assume that the increase in uterine contractions, for possible compounds also found in roots, only retard the implantation some zygotes. Such effect was already observed with extracts of other plants (Gutiérrez-Pajares et al., 2003). 
The results showed that there were no changes regarding the histology of the placenta, macroscopic appearance, size and weight of offspring. According to Leal et al. (2003) flavonoids, acridones, furanocoumarins coumarins are alkaloids with a broad spectrum of activities found in many plants. Among these, the curamins and flavonoids are present in the root of $P$. alliacea (Monache $e t$ al., 1996). Schroder et al. (1998) reported that the flavonoids of synthetic or natural origin, depending on the dosage, can cause fatal effects on the offspring during pregnancy to weaning. However, the same author also mentions that synthetic flavonoids, when administered to pregnant rats, are quickly eliminated by the mother's body through the intestine, however, they can be found all fetal tissues, including the brain. Hamann et al. (2006) reported that the natural flavonoids removed from various species of plants do not effect adult rats either, even after three months of treatment. This suggests that the different effects observed directly involve the potential for action of active compounds that can vary depending on the formulation of the extract. Another fact is that these effects vary with dose and exposure time (el Agraa et al., 2002). Thus, non-interference of hydroalcoholic extract of $P$. alliacea in the morphology of the placenta, number, size and weight of newborns may be due to the period of application and/or dosage administered. So, more research is needed with other doses of hydroalcoholic extract of $P$. alliace $a$ and perhaps for a longer period of administration, in order to validate its possible abortifacient effect, the probable morphological changes in the placenta and the possible toxic effects on offspring.

\section{ACKNOWLEDGEMENTS}

The PhD Ulysses Paulino de Albuquerque of the Department of Botany, University Federal Rural of Pernambuco, Brazil, by identification of plant $P$. alliacea.

MAIA, C. S.; WANDERLEY-TEIXEIRA, V.; TEIXEIRA, A. A. C. \& PONTES FILHO, N. T. Análisis del desarrollo fetal y placentario en ratas después de la administración de extracto hidroalcohólico de la raíz de Petiveria alliacea L. (Phytolaccaceae). Int. J. Morphol., 28(1):165-169, 2010.

RESUMEN: Se investigaron los efectos de la extracto hidroalcohólico de la raíz Petiveria alliacea sobre el desarrollo fetal y placentario en ratas preñadas. Treinta ratas hembras fueron criadas y divididas en grupos: I- Ratas tratadas con placebo y sacrificado en el día 7; II- Ratas tratadas con el extracto hidroalcohólico y sacrificadas en el día 7; III- ratas tratadas con placebo y sacrificado el día 14; IV- ratas tratadas con el extracto hidroalcohólico y sacrificaron el día 14; V- ratas tratadas con placebo para el análisis de las crías; VI- ratas tratadas con el extracto hidroalcohólico para el análisis de las crías. El extracto se administró por sonda en dosis de $18 \mathrm{mg} / \mathrm{kg}$ de peso corporal, en el $5^{\text {to }}$ día de preñez. Los sítios de implantación y la placenta se fijaron en Bouin y se procesaron para la inclusión en parafina. Las crías fueron pesadas, medidas y contadas. El extracto hidroalcohólico de la raíz de P. alliacea provocó una reducción significativa en el número de sitios de implantación, pero no causaron alteraciones histológicas en estos sitios y la placenta. No se observaron alteraciones en el número, longitud y peso de las crías. Nuestros resultados sugieren que el extracto hidroalcohólico de $P$. alliacea en la dosis de $18 \mathrm{mg} / \mathrm{kg}$ de peso corporal, administrado a ratas hembras en el $5^{\text {to }}$ día de preñez, sólo causó retardo en el proceso de implantación.

PALABRAS CLAVE: Petiveria alliacea; Útero; Placenta; Extracto hidroalcohólico.

\section{REFERENCES}

Corrêa, M. P. Dicionário das plantas úteis do Brasil e das exóticas cultivadas. $1{ }^{\text {a }}$ Ed. Rio de Janeiro, Imprensa Nacional, 1984. p.4324.

Cortez, D. A. G.; Audi, E. A.; Alberton, J. R.; Batista, W. L.; Campos, E. J. V.; Chanque, P. R. S.; Fabro, F. M.; Hossokawa, F.; Ribeiro, A. \& Rufino, M. O. Estudo da atividade ansiolítica e anti-ulcerogência da Petiveria alliaceae L. (Phytolaccaceae). Anais do XV Simpósio de Plantas Medicinais do Brasil, 1: 94, 1998.

De Lima, T. C.; Morato, G. S. \& Takahashi, R. N. Evaluation of antinociceptive effect of Petiveria alliacea (Guiné) in animals. Memorial do Instituto Oswaldo Cruz, 86:1538, 1991. el Agraa, S. E.; el Badwi, S. M. \& Adam, S. E. Preliminary observations on experimental Ruta graveolens toxicosis in Nubian goats. Trop. Anim. Health Prod., 34:271-81, 2002.

García-Gonzalez, M.; Coto Morales, T.; Ocampo, R. \& Pazos, L. Subchronic and acute preclinic toxicity and some pharmacological effects of the water extract from leaves of Petiveria alliacea (Phytolaccaceae). Rev. Biol. Trop., 54(4):1323-6, 2006.

Gomes, P. B.; Oliveira, M. M. S.; Nogueira, C. R. A.; Noronha, E. C.; Carneiro, L. M. V.; Bezerra, J. N. S., Neto, M. A.; Mendes, S. M. V.; Fonteles, M. M. F.; Viana, G. S. B. \& Sousa, F. C. F. Study of antinociceptive effect 
of isolated fractions from Petiveria alliacea L. (tipi) in mice. Biol. Pharmaceut. Bull., 28(1):42-6, 2005.

Gomes, P. B.; Noronha, E. C.; Melo, C. T.; Bezerra, J. N.; Neto, M. A.; Lino, C. S.; Vasconcelos, S. M.; Viana, G. S. \& Sousa, F. C. Central effects of isolated fractions from the root of Petiveria alliacea L. (tipi) in mice. J. Ethnopharmacol., 120(2):209-14, 2008.

Guerra, M. O.; Oliveira, A. B.; Maia, J. G. S. \& Peters, V. M. Screening of amazon native plants with a potential for inhibiting fertilization in rats. Acta Amaz., 18(12):129-34, 1989.

Gutiérrez-Pajares, J. L.; Zúñiga, L. \& Pino, J. Ruta graveolens aqueous extract retards mouse preimplantation embryo development. Reprod. Toxicol., 17(6):667-72, 2003.

Hamann, I.; Seidlova, W. D.; Wutte, W. \& Kohrle, J. Effects of isoflavonoids and other plant-derived compounds on the hypothalamus-pituitary-thyroid hormone axis. Maturitas, 55(1):S14-S25, 2006.

Leal, L. K.; Nechio, M.; Silveira, E. R.; Canuto, K. M.; Fontenele, J. B.; Ribeiro, R. A. \& Viana, G. S. Antiinflammatory and smooth muscle relaxant activities of the hydroalcoholic extract and chemical constituents from Amburana cearensis A C Smith. Phytother. Res, 17(4):335-40, 2003.

Lopes-Martins, R. A.; Pegoraro, D. H.; Woisky, R.; Penna, S. C. \& Sertié, J. A. A. The anti-inflammatory and analgesic effects of a crude extract of Petiveria alliacea L. (Phytolaccaceae). Phytomedicine, 9(3):245-8, 2002.

Monache, G. D.; Botta, B.; Vinciguerra, V.; de Mello, J. F. $\&$ de Andrade Chiappeta, A. Antimicrobial isoflavanones from Desmodium canum. Phytochemistry, 41(2):537-44, 1996.

Mors, W. B.; Rizzini, C. T. \& Pereira, N. A. Medicinal plants of Brazil. $1^{\text {th }}$ Ed. Michigan, Reference Publishing Inc., 2000.

Oluwole, F. S. \& Bolarinwa, A. F. The uterine contractile effect of Petiveria alliaceae seeds. Fitoterapia, 69(1):36, 1998.

Paria, B. C.; Song, H. \& Dey, S. K. Implantation: molecular basis of embryo-uterine dialogue. Int. J. Dev. Biol., 45(3):597-605, 2001.
Peters, V. M.; Oliveira, A. B.; Maia, J. G. \& Guerra, M. O. Efeito biológico de extratos das folhas de Petiveria alliacea na gestaçäo de ratas. Bol. Cent. Biol. Reprod., 7:31-8, 1988 .

Quadros, M. R.; Souza Brito, A. R. \& Queiroz, M. L. Petiveria alliacea $\mathrm{L}$. extract protects mice against Listeria monocytogenes infection--effects on bone marrow progenitor cells. Immunopharmacol. Immunotoxicol., 21(1):109-24, 1999.

Ruffa, M. J.; Ferraro, G.; Wagner, M. L.; Calgano, M. L.; Campos, R. H. \& Cavallaro, L. Cytotoxic effect of Argentine medicinal plant extracts on human hepatocellular carcinoma cell line. J. Ethnopharmacol., 79(3):335-9, 2002.

Schroder, J. P.; Heide, D.; Rokos, H.; Escobar, G. M. \& Kohrle, J. Synthetic flavonoids cross the placenta in the rat and are found in fetal brain. Am. J. Physiol., 274(2):E253-6, 1998.

Torres, V. M.; Ximenes, S. C. C.; Santos, E. M.; Melo, A. D.; Gomes, L. A. L.; Higino, J. S.; Sousa Filho, S. D. \& Melo, A. F. M. Avaliação bioquímica e hematológica do extrato bruto aquoso das folhas de Petiveria alliacea linn em ratos wistar. Recife, II Reunião Regional da Federação de Sociedades de Biologia Experimental, 2007.

Correspondence to:

Dra.Valéria Wanderley Teixeira

Departamento de Morfologia e Fisiologia Animal

Área de Histologia

Universidade Federal Rural de Pernambuco

Rua Dom Manoel de Medeiros s/n,

CEP 52.171-900

Dois Irmãos - Recife - PE

BRAZIL

Email: valeria@dmfa.ufrpe.br

Received: 09-09-2009

Accepted: 12-01-2010 
